\title{
Implementasi Data Mining Menggunakan Algoritma Apriori Untuk Meningkatkan Pola Penjualan Obat
}

\author{
Ramadani Saputra ${ }^{* 1}$, Alexander J.P. Sibarani ${ }^{2}$ \\ ${ }^{1,2}$ Universitas Budi Luhur; Jl. Ciledug Raya, Petukangan Utara, Jakarta Selatan, Telp. (021) \\ 5853753/Fax (021) 5853752 \\ Teknik Informatika, Fakultas Teknologi Informasi, Universitas Budi Luhur, DKI Jakarta \\ e-mail: *11 ramadani.saputra26@gmail.com, ${ }^{2}$ alexander.sibarani@ budiluhur.ac.id
}

\begin{abstract}
Abstrak
Dengan adanya kegiatan transaksi penjualan setiap hari, data semakin lama akan semakin bertambah. Data tersebut seharusnya dapat dimanfaatkan dan diolah menjadi informasi untuk meningkatan transaksi penjualan. Permasalahan yang timbul di Apotik Pusaka Arta yaitu sering sekali penjualan obat yang diinginkan konsumen tidak ada atau habis karena apotek tidak memperhatikan stok, apotek tidak memanfaatkan data transaksi penjualan yang ada dan biasanya data transaksi penjualan tersebut hanya menjadi arsip yang tidak dimanfaatkan. Untuk memecahkan masalah tersebut, maka dibuatlah aplikasi Data mining menggunakan Algoritma Apriori. Metode yang dipakai dalam menerapkan penelitian ini adalah Association Rules. Asociation Rule merupakan suatu teknik dalam data mining untuk menentukan hubungan antar item dalam satu data set (sekumpulan data) yang telah ditentukan. Teknik ini mencari kemungkinan kombinasi yang sering muncul (frequenct) dari suatu itemset (sekumpulan item). Dalam penelitian ini Association Rule berfungsi untuk menganalisa seberapa sering suatu obat yang sering dijual secara bersamaan, analisis ini akan ditinjau dari data transaksi yang telah terjadi. Penerapan Algoritma Apriori dalam aplikasi ini berhasil mencari kombinasi item terbanyak berdasarkan data transaksi dan kemudian membentuk pola asosiasi dari kombinasi item tersebut. Hasil aplikasi ini dapat mengetahui jenis obat yang sering dibeli oleh konsumen secara bersamaan sehingga dapat mengetahui pola penjualan obat.
\end{abstract}

Kata kunci-Data Mining, Algoritma Apriori, Association Rules, Penjualan Obat

\begin{abstract}
With the existence of sales transactions every day, the longer the data will be more and more. The data not only serves as an archive for the company, the data can be used and processed into information to increase drug sales. The problem that often arises in Arta Pusaka Pharmacy is that drug sales that consumers want often do not exist or run out because the pharmacy does not pay attention to stock, the pharmacy does not utilize existing sales transaction data and usually the sales transaction data is only an archive that is not utilized. To solve this problem, a data mining application was made using the Apriori Algorithm. The method used by the author in applying this research is Association Rules. Association Rule is a technique in data mining to determine the relationships between items in a data set (set of data) that has been determined. This technique looks for possible combinations that frequently occur (frequenct) of an itemset ( $a$ group of items). In this research, the Association Rule serves to analyze frequently several drugs that are often sold simultaneously, this analysis will be reviewed from the transaction data that has occurred. The application of the Apriori Algorithm in this application succeeded in finding the most combination of items based on transaction data and then formed the association pattern of that item combination. The results of this application can find out what drugs are often purchased by consumers simultaneously so they can know the pattern of drug sales.
\end{abstract}


Keywords—Data Mining, Apriori, Algorithm, Association Rules, drug sales

\section{PENDAHULUAN}

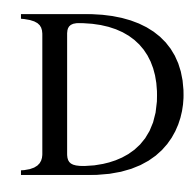
alam ersaingan di dunia bisnis khususnya dalam industri apotek, menuntut para pengusaha untuk menemukan suatu strategi pemasaran yang dapat meningkatkan penjualan obat. Salah satu cara untuk meningkatkan jumlah transaksi penjualan obat adalah dengan memanfaatkan data transaksi jenis dan penjualan obat. Setiap masalah penjualan obat diapotek selalu dicatat. Data transaksi penjualan ini dapat diolah untuk menemukan pola tertentu dalam penjulan obat dalam priode tertentu. Apotik Pusaka Arta merupakan salah satu usaha yang bergerak dibidang pelayanan kesehatan, dimana memiliki aktivitas transaksi penjualan yang begitu banyak. Apabila data transaksi penjualan di analisa maka dapat diketahui pola yang sangat membantu dalam memajukan apotek.

Dengan adanya kegiatan transaksi penjualan setiap hari, data semakin lama akan semakin bertambah banyak. Data tersebut tidak hanya berfungsi sebagai arsip, data tersebut dapat dimanfaatkan dan diolah menjadi informasi yang berguna untuk peningkatan penjualan obat. Permasalahan yang sering timbul yaitu sering sekali penjualan obat yang diinginkan konsumen tidak ada atau habis karena apotek tidak memperhatikan stok, apotek tidak memanfaatkan data transaksi penjualan yang ada dan biasanya data transaksi penjualan tersebut hanya menjadi arsip yang tidak dimanfaatkan. Hal ini tentu menjadi kerugian bagi apotek, disebabkan persediaan obat di apotek tidak terkontrol dengan baik. Pada dasarnya kumpulan data tersebut memiliki informasi- informasi yang bermanfaat, yang bisa digunakan untuk mengambil suatu keputusan dan untuk memperoleh pengetahuan yang baru tentang pola penjualan obat. Pengolahan data tersebut bisa dilakukan dengan menggunakan teknik-teknik tertentu. Salah satu teknik yang digunakan dalam pengolahan data tersebut dengan menggunakan metode Algoritma Apriori.

Algoritma Apriori adalah algoritma pengambilan data dengan aturan asosiatif (Association rule) untuk menentukan hubungan asosiatif suatu kombinasi item. Association Rule yang dimaksud dilakukan melalui mekanisme penghitungan support dan confidence dari suatu hubungan item. Sebuah aturan asosiasi dikatakan interesting jika nilai support adalah lebih besar dari minimum support dan juga nilai confidence adalah lebih besar dari minimum confidence [1]. Algoritma Apriori ini akan cocok untuk diterapkan bila terdapat beberapa hubungan item yang ingin dianalisa. Oleh sebab itu metode Algoritma Apriori dapat digunakan untuk mengetahui analisa pada pola transaksi penjualan obat. Dengan penerapan Algoritma Apriori dapat membantu menemukan jenis obat yang paling banyak terjual yang nantinya akan digunakan sebagai acuan pemesanan obat selanjutnya. Pada penelitian sebelumnya, sudah terdapat beberapa pemanfaatan data mining menggunakan metode tertentu untuk mendapatkan pola terhadap penjualan barang maupun penempatan lokasi barang.

Seperti pada penelitian yang dilakukan oleh Robi Yanto dkk (2017), tema penelitian adalah memanfaatkan data mining untuk mendapatkan pola penempatan buku di perpustakaan, namun metode yang digunakan adalah Association Rule. Penentuan pola penempatan buku yang dilakukan berdasarkan 3 item set buku [2]. Terdapat juga penelitian yang dilakukan oleh Kennedi Tampubolon dkk (2013), dimana penelitian mengambil topik implementasi data mining pada sistem persediaan alat-alat kesehatan menggunakan metode apriori. Hasil dari penelitian tersebut didapatkan pola kombinasi item set hasil penjualan alat-alat kesehatan di apotik [3]. Terdapat juga penelitian pemanfaatan data mining yang menggunakan dua algoritma, seperti yang dilakukan oleh Goldie Gunadi dkk (2012), penelitian berfokus pada market basket analysis terhadap data 
penjualan produk buku di salah satu toko buku. Algoritma yang digunakan adalah Apriori dan Frequent Pattern Growth (FP-Growth) [4].

\subsection{Data Mining}

Data mining merupakan bidang dari beberapa bidang keilmuan yang menyatukan teknik dari pembelajaran mesin, pengenalan pola, statistik, database dan visualisasi untuk pengenalan permasalahan pengambilan informasi dari database yang besar [5]. Sementara dalam pengertian lain, Data mining merupakan suatu proses pencarian pola dari data-data dengan jumlah yang sangat banyak yang tersimpan dalam suatu tempat penyimpanan dengan menggunakan teknologi pengenal pola, teknik statistik, dan matematika [6].

Karakteristik data mining adalah sebagai berikut [7]:

a. Data mining berhubungan dengan penemuan sesuatu yang tersembunyi dan pola data tertentu yang tidak diketahui sebelumnya.

b. Data mining biasa menggunakan data yang sangat besar.

c. Biasanya data yang besar digunakan untuk membuat hasil lebih dipercaya.

d. Data mining berguna untuk membuat keputusan yang kritis, terutama dalam strategi.

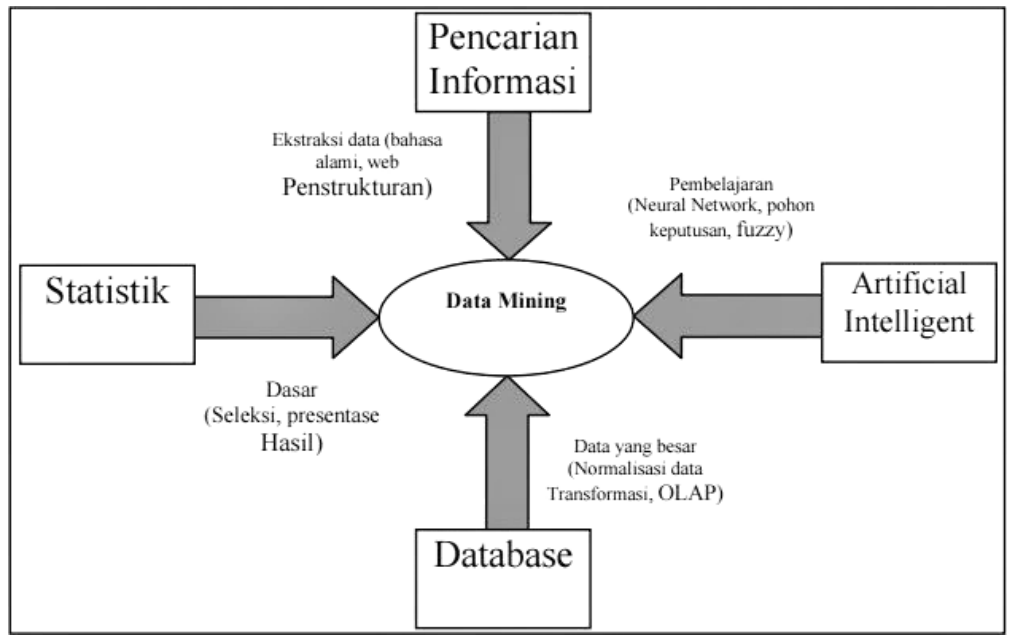

Gambar 1. Bidang Ilmu Data Mining [10]

Data mining, sering juga disebut knowledge discovery in database (KDD), adalah kegiatan yang meliputi pengumpulan, pemakaian data historis untuk menemukan keteraturan, pola atau hubungan dalam set data berukuran besar. Keluaran dari data mining bisa dipakai untuk memperbaiki pengambilan keputusan dimasa depan. Sehingga istiah pattern recognition sekarang jarang di gunakan karena termasuk bagian dari data mining [8].

Metode data mining yang digunakan dalam pengembangan aplikasi ini men.gikuti salah satu metode yang sudah dijadikan standar yaitu Cross-Industry Standard Process for Data Mining (CRISP-DM). Proses CRISP-DM dibagi ke dalam enam tahap yang digambarkan pada gambar 2 berikut. 


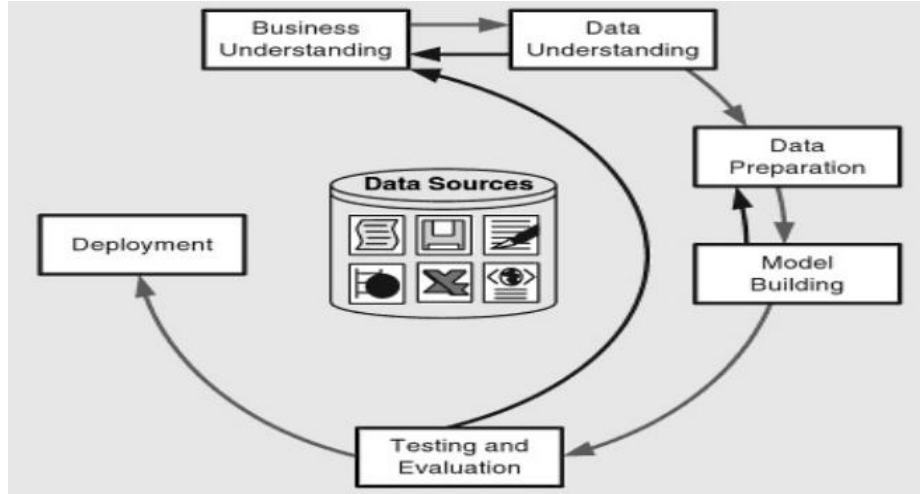

Gambar 2. Cross-Industry Standard Process for Data Mining (CRISP-DM) [9]

\subsection{Proses Data Mining}

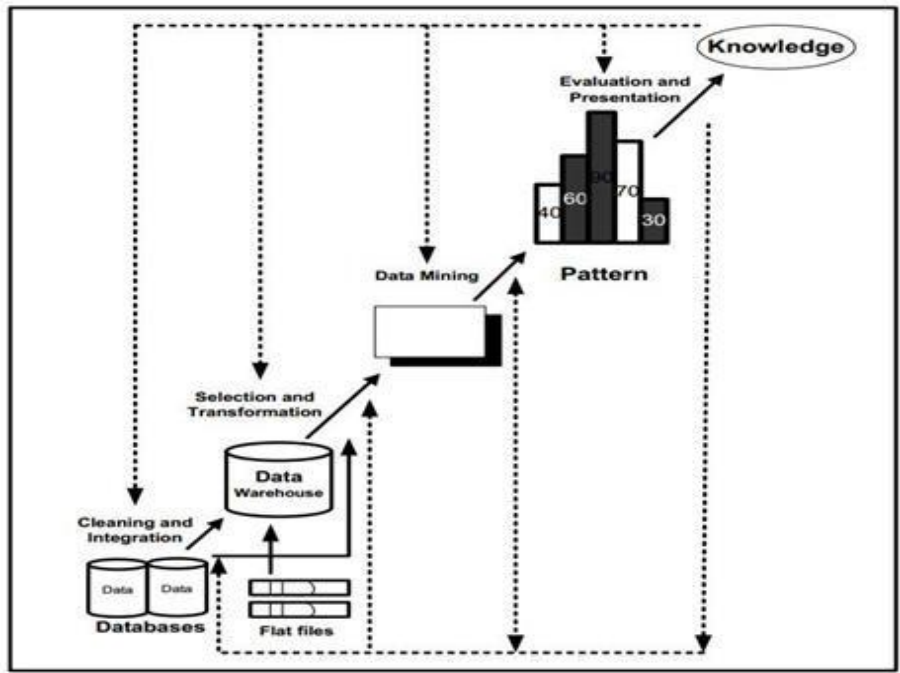

Gambar 3. Proses Data Mining [2]

Tahapan-tahapan proses data mining, diantaranya [5]:

a. Pembersihan data (Data cleaning)

Pembersihan data merupakan proses menghilangkan noise dan data yang tidak konsisten atau data tidak relevan.

b. Integrasi data (Data integration)

Integrasi data merupakan penggabungan data dari berbagai database ke dalam satu database baru.

c. Seleksi data (Data selection)

Data yang ada pada database sering kali tidak semuanya dipakai, oleh karena itu hanya data yang sesuai untuk dianalisis atau yang cocok dengan data uji yang akan diambil dari database.

d. Transformasi data (Data transformation)

Data diubah atau digabung ke dalam format yang sesuai untuk diproses dalam data mining.

e. Proses mining

Merupakan suatu proses utama saat metode diterapkan untuk menemukan pengetahuan berharga dan tersembunyi dari data.

Saputra, et., al (Implementasi Data Mining Menggunakan Algoritma Apriori Untuk Meningkatkan Pola Penjualan Obat) 
f. Evaluasi pola (Pattern evaluation)

Untuk mengidentifikasi pola-pola knowledge based yang ditemukan. Dalam tahap ini hasil dalam teknik data mining berupa pola-pola yang khas maupun model prediksi dievaluasi untuk menilai apakah hipotesa yang ada memang tercapai.

g. Presentasi pengetahuan (Knowledge presentation)

Merupakan visualisasi dan penyajian pengetahuan mengenai metode yang digunakan untuk memperoleh pengetahuan yang diperoleh pengguna.

\subsection{Algoritma Apriori}

Algoritma Apriori termasuk jenis aturan asosiasi pada data mining. Selain apriori, yang termasuk pada golongan ini adalah metode Generalized Rule Induction dan Algoritma Hash Based. Aturan yang menyatakan asosiasi antara beberapa atribut sering disebut affinity analysis atau market basket analysis [11].

Algoritma apriori dibagi menjadi beberapa tahap yang disebut narasi [11]. Tahapannya adalah sebagai berikut:

a. Pembentukan kandidat itemset. Kandidat k-itemset dibentuk dari kombinasi (k-1) itemset yang didapat dari iterasi sebelumnya. Cara dari algoritma apriori adalah pemangkasan kandidat k-itemset yang subsetnya berisi k-1 item tidak termasuk dalam pola frekuensi tinggi dengan panjang $\mathrm{k}-1$.

b. Penghitungan support dari tiap kandidat k-itemset. Support dari tiap kandidat k-itemset didapat dengan men-scan database untuk menghitung jumlah transaksi yang memuat semua item didalam kandidat k-itemset tersebut. Ini adalah juga ciri dari algoritma apriori dimana diperlukan penghitungan dengan cara seluruh database sebanyak k-itemset terpanjang.

c. Tetapkan pola frekuensi tinggi. Pola frekuensi tinggi yang memuat $\mathrm{k}$ item atau k-itemset ditetapkan dari kandidat k-itemset yang supportnya lebih besar dari minimum support.

d. Bila tidak didapat pola frekuensi tinggi baru maka seluruh proses dihentikan.

\subsection{Association Rules}

Association Rule atau Aturan Asosiasi adalah teknik data mining untuk menemukan aturan asosiatif atau pola kombinasi dari suatu item. Bila kita mengambil contoh aturan asosiatif dalam suatu transaksi pembelian barang disuatu minimarket adalah kita dapat mengetahui berapa besar kemungkinan seorang konsumen membeli suatu item bersamaan dengan item lainnya [12].

1. Analisis pola frekuensi tinggi

Nilai Support (nilai penunjang) merupakan presentase dari record-record yang mengandung kombinasi.

$$
\operatorname{Support}(A)=\frac{\sum \text { Transaksi mengandung }(A) \times 100}{\text { Total Transaksi }(A)}
$$

2. Pembentukan Aturan Asosiasi

Akurasi dari suatu association rule sering disebut dengan confidence. Confidence (nilai kepastian) adalah kuatnya hubungan antara item dalam aturan asosiatif.

$$
\text { Confidence }(A=>B) \underset{\text { Support }(A)}{\operatorname{Support}(A \text { dan } B)} \times 100
$$




\section{METODE PENELITIAN}

\subsection{Analisa Masalah}

Diketahui bahwa dalam menyimpan dan mengolah data-data transaksi yang ada telah menggunakan sistem komputerisasi, namun pada sistem tersebut tidak terdapat suatu aplikasi yang dapat membantu manajer untuk menganalisa data transaksi penjualan yang ada. Aplikasi ini diharapkan dapat membantu mempermudah manajer dalam menganalisa data transaksi penjualan yang terjadi setiap harinya, serta dapat membantu manajer untuk mengetahui strategi penjualan dan tata letak obat yang dijual.

\subsection{Strategi Pemecahan Masalah}

Pada analisa masalah diatas, untuk memecahkan masalah tersebut, maka dibuatlah aplikasi Data Mining menggunakan Algoritma Apriori berbasis web. Metode yang dipakai dalam menerapkan penelitian ini adalah Association Rules. Asociation Rule merupakan suatu teknik dalam data mining untuk menentukan hubungan antar item dalam satu data set (sekumpulan data) yang telah ditentukan. Aplikasi ini nantinya diharapkan tidak hanya dapat memprediksi transaksi apa saja yang akan terjadi berikutnya, namun diharapkan juga dapat merancang tata letak obat yang dijual berdasarkan pola hubungan antara obat demi meningkatkan terjadinya pembelian.

\subsection{Rancangan Basis Data}

Gambar 3 di bawah ini adalah rancangan class diagram yang digunakan pada spesifikasi data mining untuk pencarian pola penjualan pada Apotik Pusaka Arta.

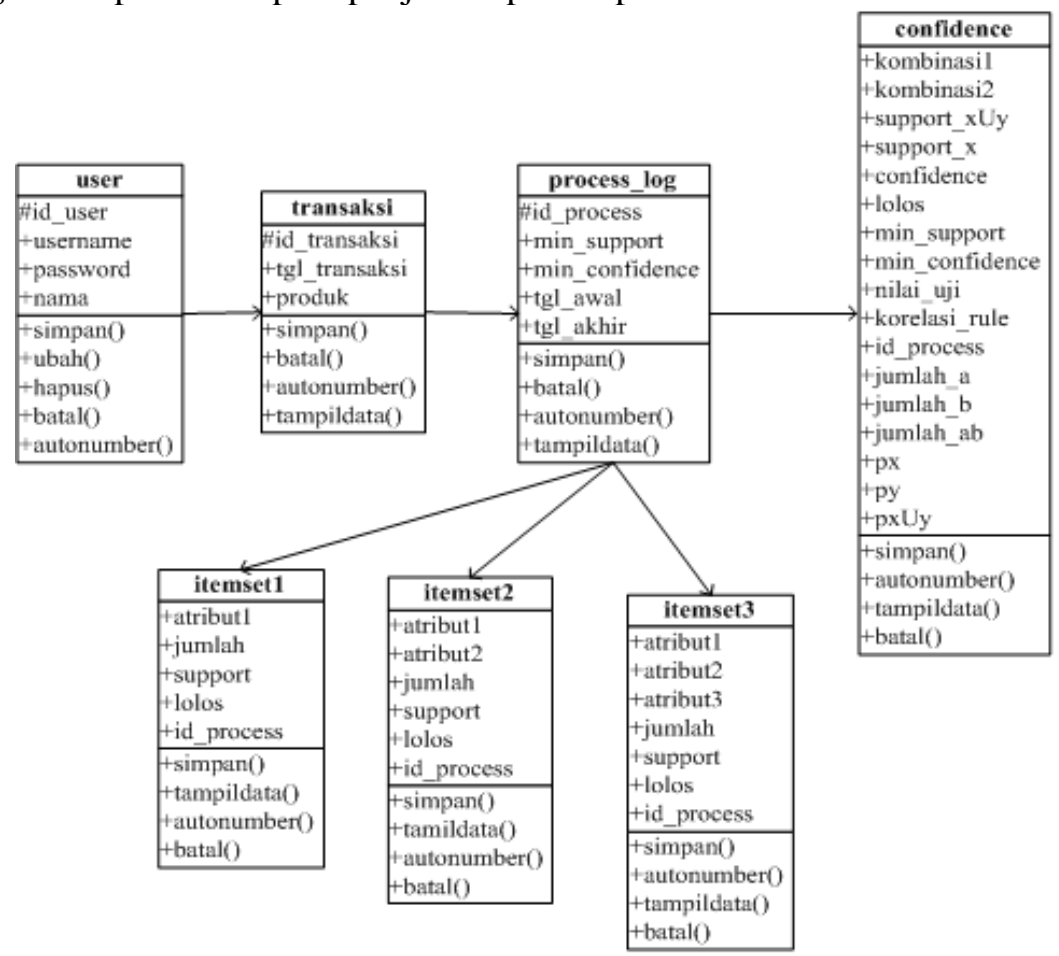

Gambar 3. Class Diagram

Saputra, et., al (Implementasi Data Mining Menggunakan Algoritma Apriori Untuk Meningkatkan Pola Penjualan 


\subsection{Flowchart}

Untuk mempermudah memahami alur proses program pada aplikasi ini maka dibuat flowchart untuk masing-masing proses. Gambar 4 merupakan flowchart halaman utama setelah selesai melakukan proses login. Pada halaman utama terdapat menu untuk menuju proses selanjutnya seperti data transaksi, proses apriori, dan hasil rule untuk melakukan proses mining data transaksi.

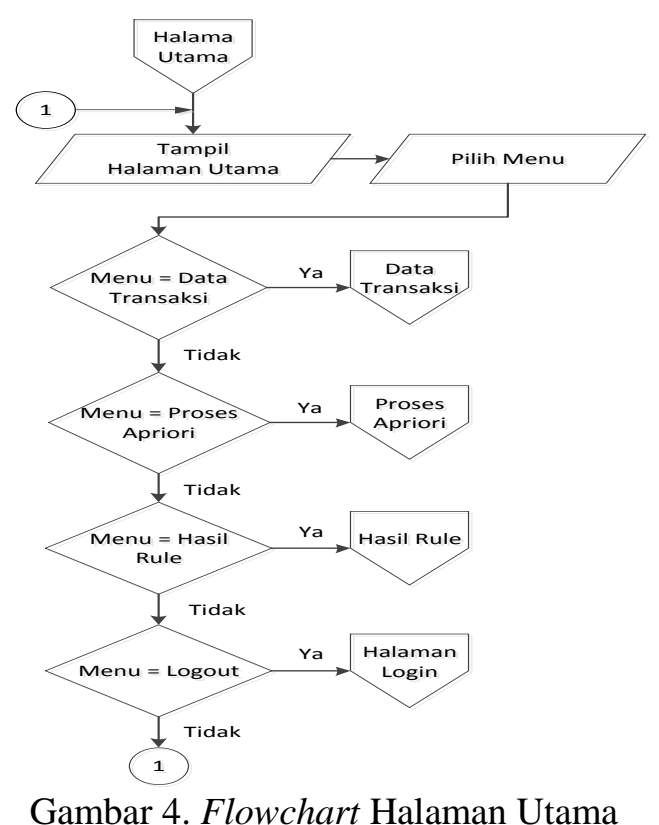

Gambar 5 merupakan flowchart proses data transaksi. Admin memasukan data transaksi yang akan diolah untuk proses mining. Admin juga dapat menghapus data transaksi jika diperlukan. Pada tahapan ini dilakukan proses upload data dari file excel. Proses pembersihan data dilakukan pada proses flowchart ini.

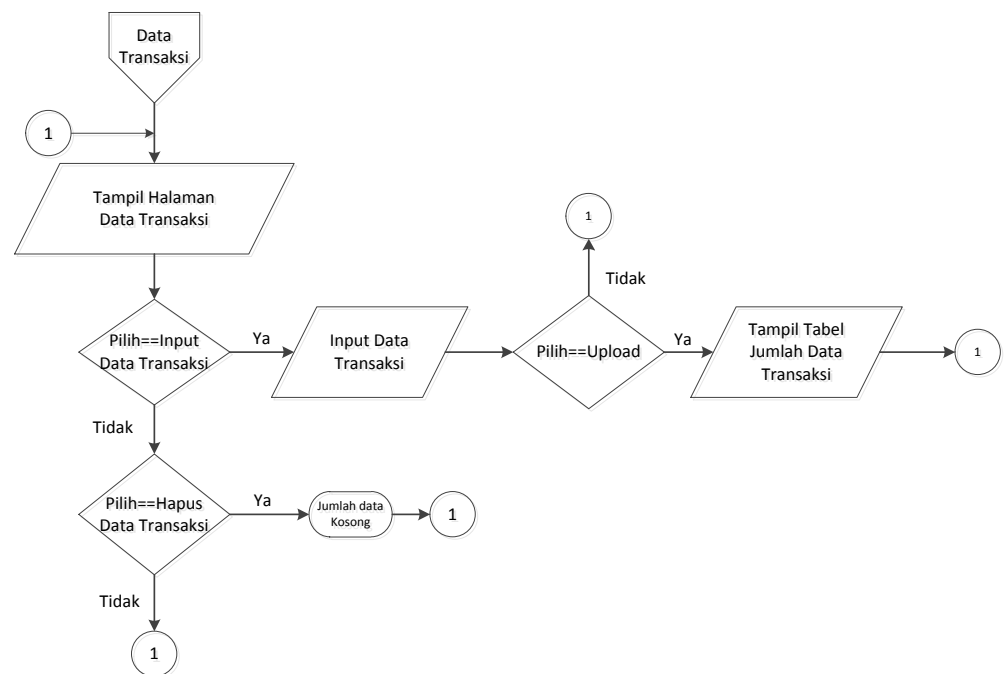

Gambar 5. Flowchart Data Transaksi

Saputra, et., al (Implementasi Data Mining Menggunakan Algoritma Apriori Untuk Meningkatkan Pola Penjualan Obat) 
Gambar 6 merupakan flowchart dimana Admin melakukan proses mining data transaksi yang telah dimasukan dengan menentukan Min Support, Min Confidence dan periode Tanggal dari data transaksi.

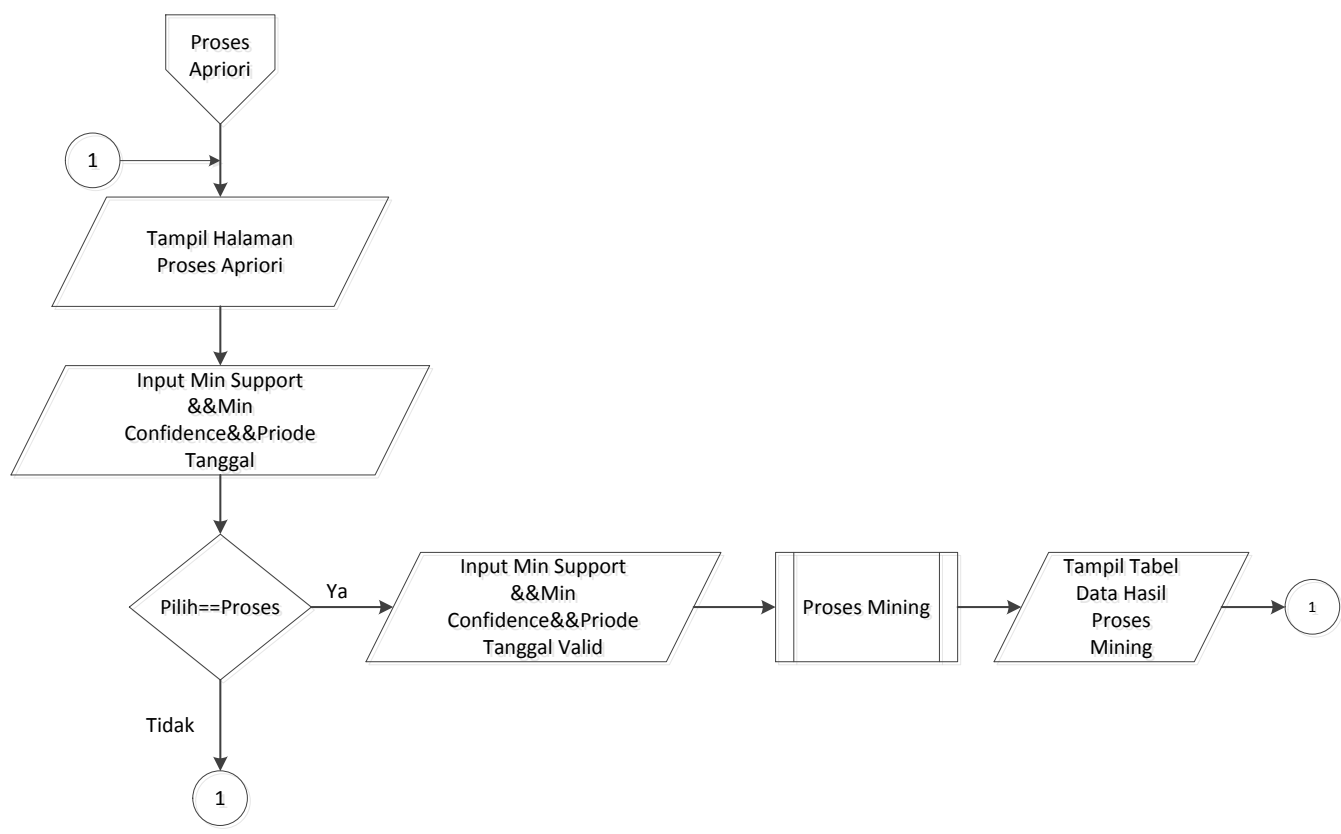

Gambar 6. Flowchart Halaman Proses Apriori

Flowchart pada gambar 7 dan gambar 8 merupakan halaman User. Beranda User hanya dapat melihat Hasil rule dari proses mining data transaksi.

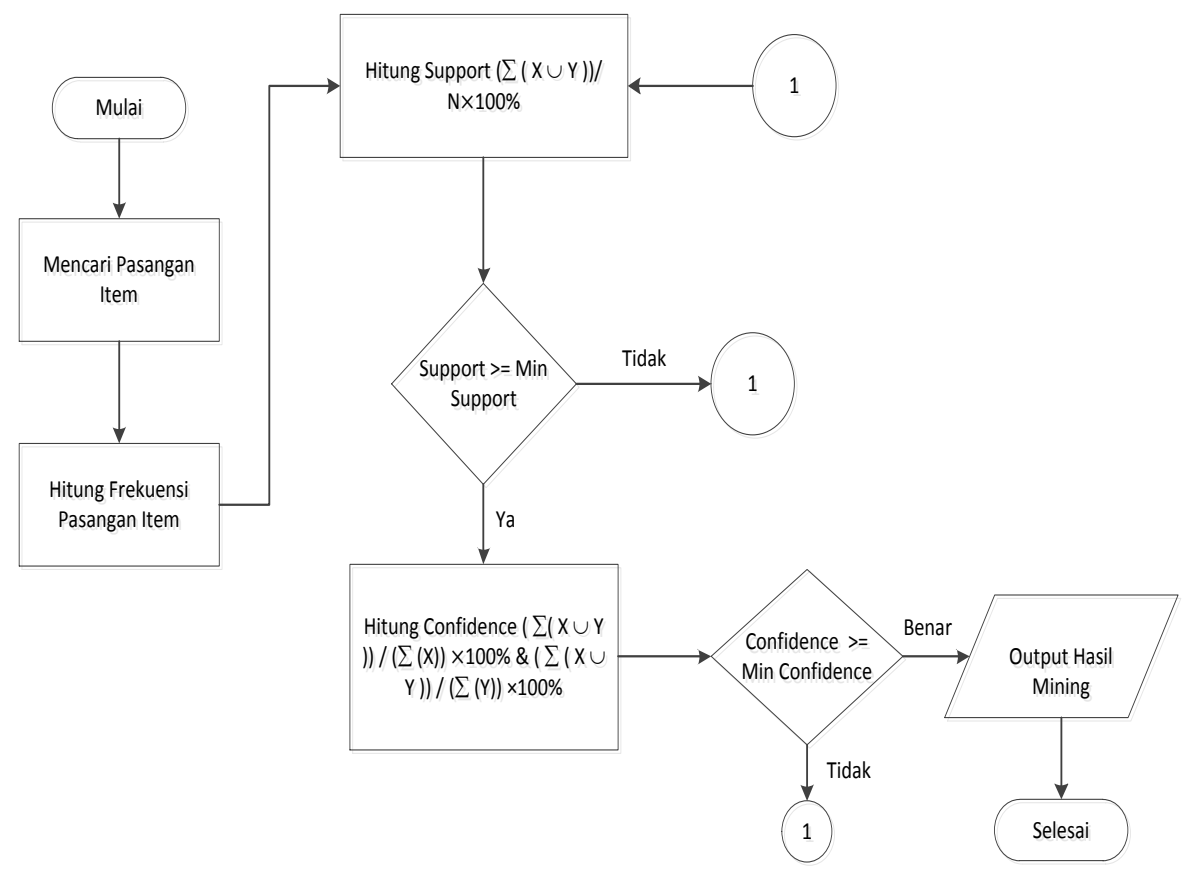

Gambar 7. Flowchart Proses Mining

Saputra, et., al (Implementasi Data Mining Menggunakan Algoritma Apriori Untuk Meningkatkan Pola Penjualan Obat) 


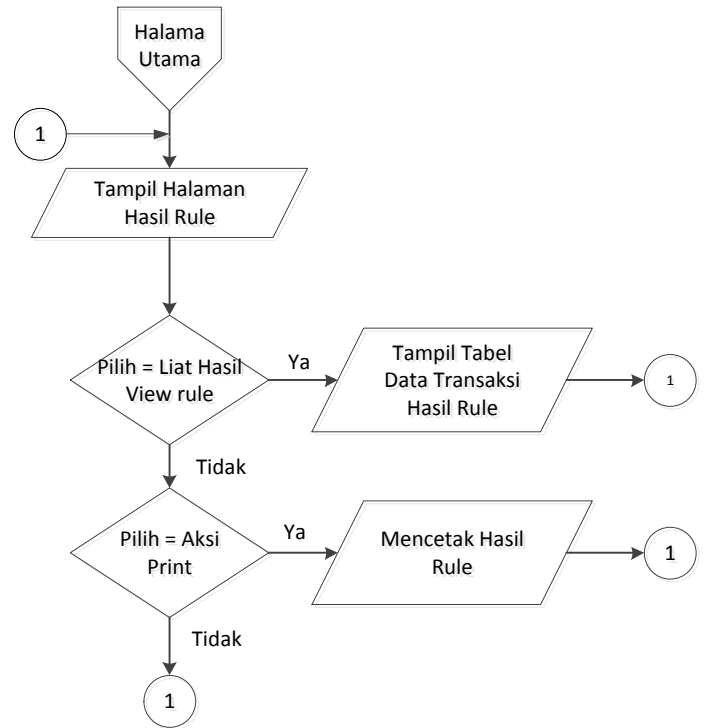

Gambar 8. Flowchart Hasil Rule

\section{HASIL DAN PEMBAHASAN}

\subsection{Pengujian Data Transaksi}

Pada halaman data transaksi sebagaimana ditunjukkan pada Gambar 9, admin memasukan file data transaksi yang akan diolah untuk proses mining. File data transaksi upload yang di-input haruslah berformat .xls atau file microsoft excel. Admin juga dapat menghapus data transaksi bila diperlukan. Proses pembersihan data (data cleaning) dilakukan pada halaman data transaksi.

\section{Data Mining Apotik Pusaka Arta}

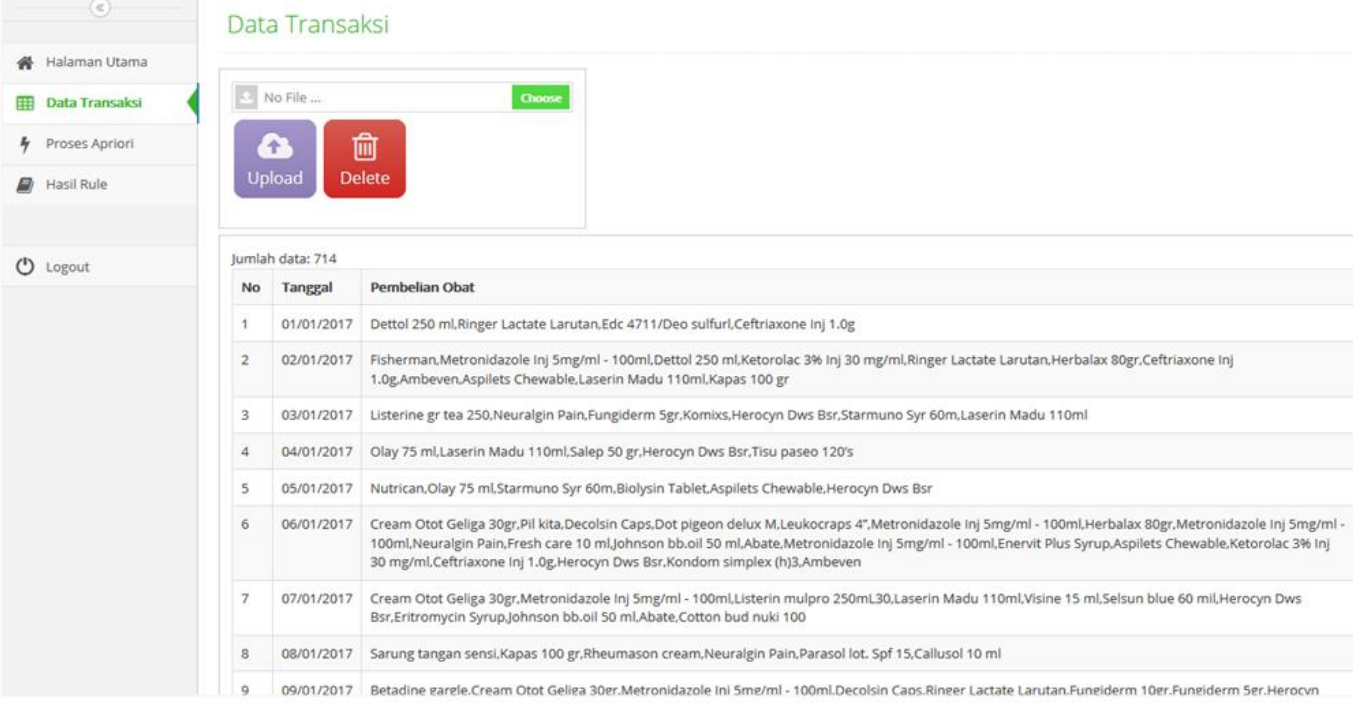

Gambar 9. Pengujian Data Transaksi

Saputra, et., al (Implementasi Data Mining Menggunakan Algoritma Apriori Untuk Meningkatkan Pola Penjualan Obat) 


\subsection{Pengujian pada Halaman Proses Apriori}

Data transaksi yang telah di-input kemudian diolah pada halaman Proses Apriori, pada halaman ini admin menentukan minimum support 20 dan minimum confidence 50 serta menentukan data transaksi yang akan dihitung dengan periode data transaksi yang dapat dipilih. Terlihat seperti gambar 10 dibawah ini:

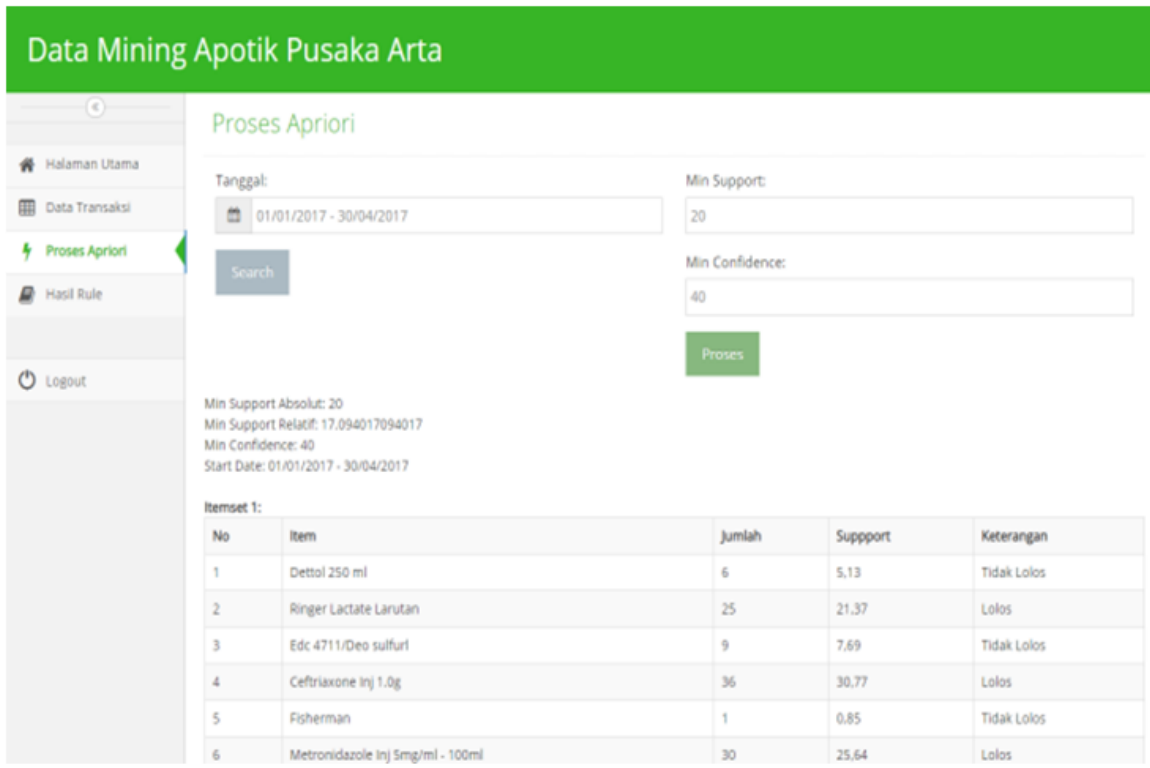

Gambar 10. Pengujian pada Proses Apriori

Pada Halaman Proses Apriori ke bawah akan melihat proses mining yang telah berhasil dilakukan seperti gambar 11 berikut.

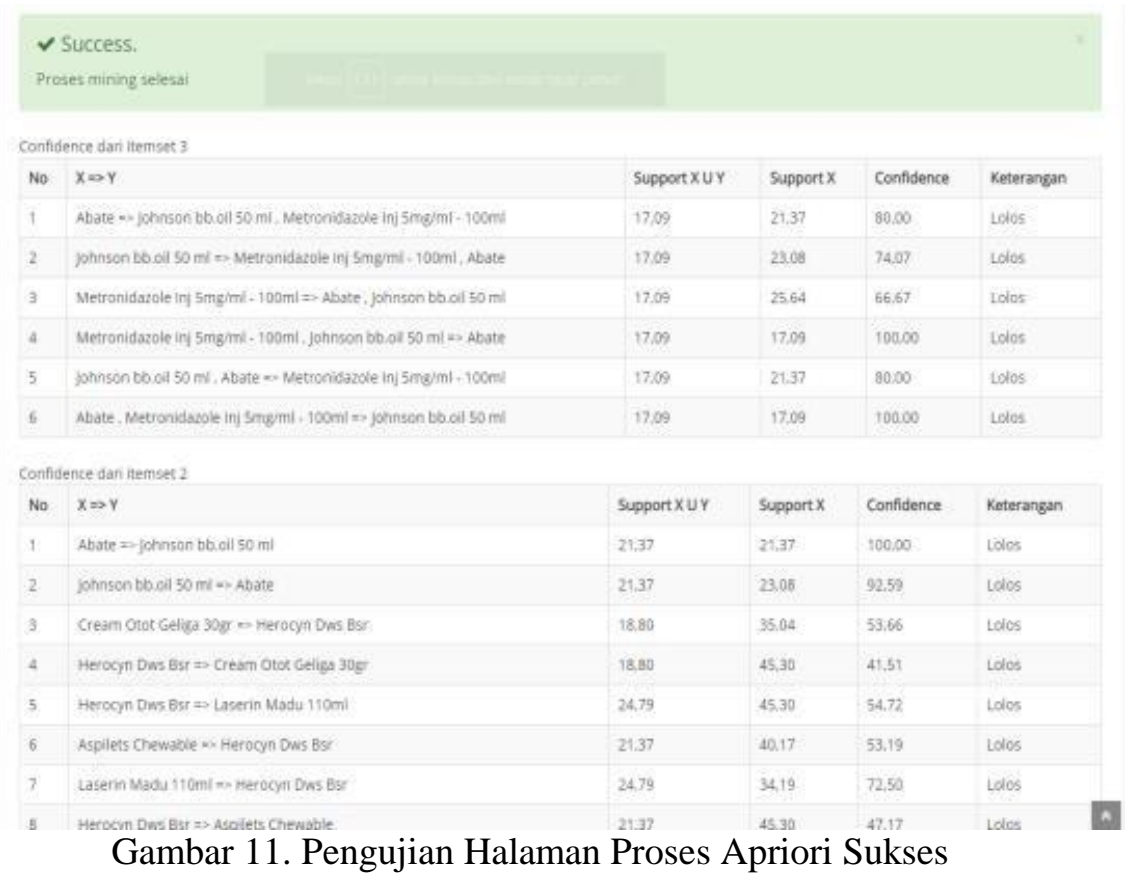

Saputra, et., al (Implementasi Data Mining Menggunakan Algoritma Apriori Untuk Meningkatkan Pola Penjualan Obat) 
Disini proses mining yang sudah berhasil diproses dan sukses, dan akan dilanjutkan ke hasil rule dan dapat melihat nilai asosiasinya.

\subsection{Pengujian Hasil Proses Mining pada Halaman Proses Apriori}

Analisa ini bertujuan untuk mengetahui kinerja program. Pada gambar 12 dibawah ini merupakan hasil dari proses mining yang dilakukan dengan memasukan min_support sebesar $20 \%$ dan min_confidence sebesar 50\% serta periode tanggal transaksi yang dapat dipilih. Pengujian ini mencakup akurasi yang didapat berdasarkan nilai dari hasil prediksi. Dari berbagai uji coba yang dilakukan, dengan nilai min_support sebesar $20 \%$ dan min_confidence sebesar $50 \%$ diperoleh hasil maksimal terhadap itemset yang dihasilkan yaitu itemset 1 , itemset 2 , dan itemset 3 .

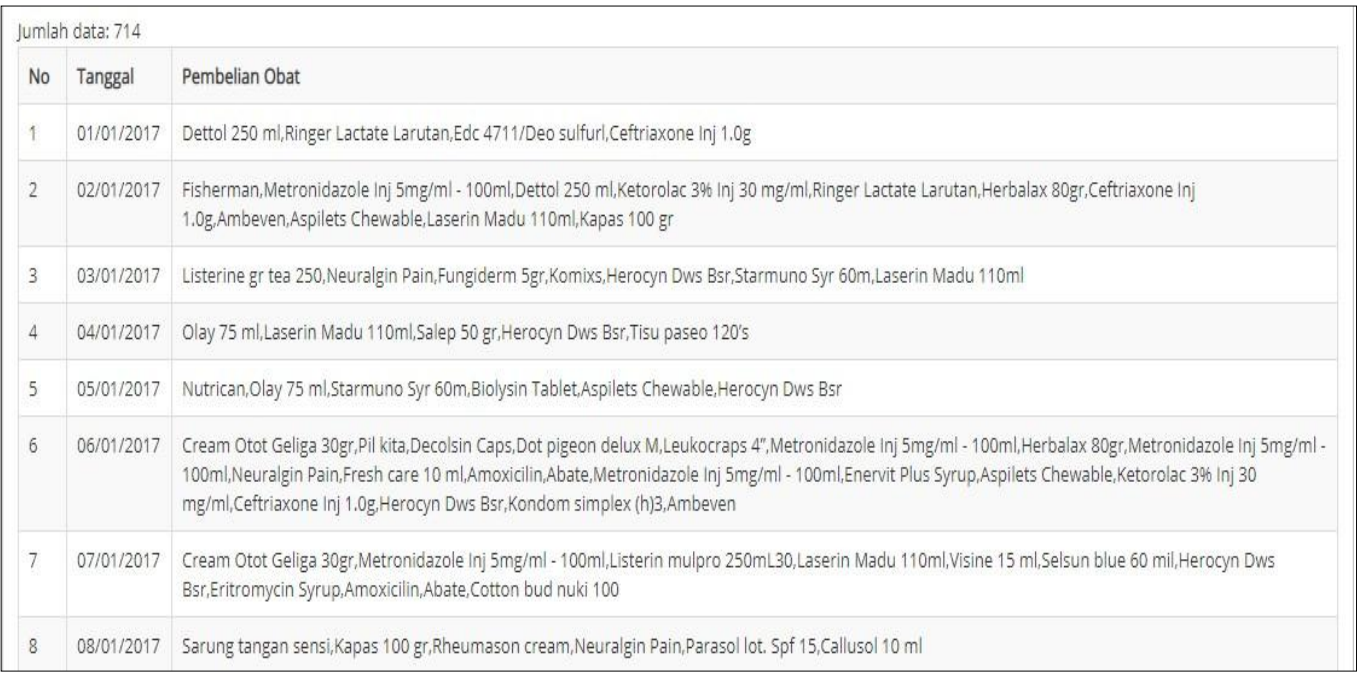

Gambar 12. Data Transaksi Obat

Tabel 1. Perhitungan Support dari Itemset 1

\begin{tabular}{|c|l|c|c|c|}
\hline No & \multicolumn{1}{|c|}{ Item 1 } & Jumlah & Support (\%) & Keterangan \\
\hline 1 & Herocyn Dws Bsr & 53 & 45,30 & Lolos \\
\hline 2 & Starmuno Syr 60m & 25 & 21,37 & Lolos \\
\hline 3 & Cream Otot Geliga 30gr & 41 & 35,04 & Lolos \\
\hline 4 & Fungiderm 5gr & 22 & 18,80 & Lolos \\
\hline 5 & Eritromycin Syrup & 25 & 21,37 & Lolos \\
\hline 6 & Laserin Madu 110ml & 40 & 34,19 & Lolos \\
\hline 7 & Aspilets Chewable & 47 & 40,17 & Lolos \\
\hline 8 & Ambeven & 24 & 20,51 & Lolos \\
\hline 9 & Ceftriaxone Inj 1.0g & 36 & 30,77 & Lolos \\
\hline 10 & Metronidazole Inj 5mg/ml 100ml & 30 & 25,64 & Lolos \\
\hline
\end{tabular}

Tabel 1 merupakan awal perhitungan nilai support Itemset 1 yang digunakan untuk mendapatkan hasil yang lolos atau tidak lolos. Sebagai contoh untuk item Herocyn Dws Bsr 
dengan perhitungan nilai mengandung jumlah transaksi obat terjual 53, Total Transaksi 117 dan akan didapat nilai 45.30 yang berasal dari 53/117 $\times 100 \%=45.30$

Tabel 2. Perhitungan Support dari Itemset 2

\begin{tabular}{|c|l|l|c|c|c|}
\hline No & \multicolumn{1}{|c|}{ Item 1 } & Item 2 & Jumlah & $\begin{array}{c}\text { Support } \\
(\mathbf{\%})\end{array}$ & Keterangan \\
\hline 1 & $\begin{array}{l}\text { Metronidazole Inj } \\
5 \mathrm{mg} / \mathrm{ml}-100 \mathrm{ml}\end{array}$ & Amoxicilin & 20 & 17,09 & Lolos \\
\hline 2 & $\begin{array}{l}\text { Metronidazole Inj } \\
5 \mathrm{mg} / \mathrm{ml}-100 \mathrm{ml}\end{array}$ & $\begin{array}{l}\text { Cream Otot } \\
\text { Geliga 30gr }\end{array}$ & 21 & 17,95 & Lolos \\
\hline 3 & $\begin{array}{l}\text { Metronidazole Inj } \\
5 \mathrm{mg} / \mathrm{ml}-100 \mathrm{ml}\end{array}$ & Abate & 20 & 17,09 & Lolos \\
\hline 4 & Laserin Madu 110ml & $\begin{array}{l}\text { Herocyn Dws } \\
\text { Bsr }\end{array}$ & 29 & 24,79 & Lolos \\
\hline 5 & Herocyn Dws Bsr & $\begin{array}{l}\text { Cream Otot } \\
\text { Geliga 30gr }\end{array}$ & 22 & 18,80 & Lolos \\
\hline 6 & Ceftriaxone Inj 1.0g & $\begin{array}{l}\text { Cream Otot } \\
\text { Geliga 30gr }\end{array}$ & 31 & 26,50 & Lolos \\
\hline
\end{tabular}

Tabel 2 merupakan perhitungan transaksi antara item 1 dan item 2 yang muncul secara bersama. Hasil transaksi digunakan untuk mendapatkan hasil yang lolos atau tidak lolos. Sebagai contoh, untuk item 1 dan item 2, Metronidazole Inj dan Amoxicilin, nilai support didapat dari $20 / 117 \times 100=17.09$.

Min_support relatif didapat dari 20/117 $\times 100=17.09$, dimana nilai 20 adalah nilai min_support dibagi nilai jumlah transaksi dari periode yang diolah. Artinya, jika nilai perhitungan dibawah min_support relatif $17.09 \%$, statusnya Tidak Lolos.

Tabel 3. Perhitungan Support dari Itemset 3

\begin{tabular}{|c|l|c|c|c|c|l|}
\hline No & \multicolumn{1}{|c|}{ Item 1 } & Item 2 & Item 3 & Jumlah & $\begin{array}{c}\text { Support } \\
(\%)\end{array}$ & Keterangan \\
\hline 1 & $\begin{array}{l}\text { Metronidazole } \\
\text { Inj 5mg/ml - 100ml }\end{array}$ & Amoxicilin & Abate & 20 & 17,09 & Lolos \\
\hline 2 & Amoxicilin & $\begin{array}{c}\text { Herocyn Dws } \\
\text { Bsr }\end{array}$ & Abate & 11 & 9,40 & Tidak Lolos \\
\hline 3 & Laserin Madu 110ml & Amoxicilin & $\begin{array}{c}\text { Herocyn Dws } \\
\text { Bsr }\end{array}$ & 5 & 4,27 & Tidak Lolos \\
\hline 5 & $\begin{array}{l}\text { Metronidazole Inj } \\
5 \mathrm{mg} / \mathrm{ml}-100 \mathrm{ml}\end{array}$ & Amoxicilin & $\begin{array}{c}\text { Herocyn Dws } \\
\text { Bsr }\end{array}$ & 11 & 9,40 & Tidak Lolos \\
\hline
\end{tabular}

Tabel 3 merupakan gabungan atara item 1, item 2 dan item 3 transaksi yang mucul secara bersama. Jika nilai min_support diatas $17.09 \%$ akan muncul keterangan lolos, jika dibawah akan tidak lolos. 
Support $=\frac{20}{117} \times 100 / \frac{(\text { item } 1, \text { item 2, item 3) }}{\text { Total Transaksi }} \times 100$

Tabel 4. Confidence Itemset 3

\begin{tabular}{|c|l|c|c|c|c|}
\hline No & \multicolumn{1}{|c|}{$\mathbf{X}=>\mathbf{Y}$} & $\begin{array}{c}\text { Support X U } \\
\mathbf{Y}(\mathbf{\%})\end{array}$ & $\begin{array}{c}\text { Support X } \\
(\mathbf{\%})\end{array}$ & $\begin{array}{c}\text { Confidence } \\
(\mathbf{\%})\end{array}$ & Keterangan \\
\hline 1 & $\begin{array}{l}\text { Metronidazole Inj 5mg/ml - } \\
\text { 100ml, } \\
\text { Amoxicilin => Abate }\end{array}$ & 17,09 & 17,09 & 100,00 & Lolos \\
\hline 2 & $\begin{array}{l}\text { Amoxicilin, Abate => } \\
\text { Metronidazole Inj 5mg/ml - } \\
\text { 100ml }\end{array}$ & 17,09 & 21,37 & 80,00 & Lolos \\
\hline 3 & $\begin{array}{l}\text { Abate, Metronidazole Inj } \\
\text { 5mg/ml - 100ml => } \\
\text { Amoxicilin }\end{array}$ & 17,09 & 17,09 & 100,00 & Lolos \\
\hline
\end{tabular}

Tabel 4 merupakan perhitungan confidence gabungan itemset 1, 2, dan 3 yang lolos. Selain itu Jika nilai confidence diatas $50 \%$ akan muncul keterangan lolos, jika dibawah akan menampilkan keterangan tidak lolos.

Confidence $(\mathrm{X}=>\mathrm{Y})=$

$\frac{\text { Support }(\mathrm{X} \text { dan } \mathrm{Y})}{\text { Support }(\mathrm{X})} \times 100$ atau Confidence $(\mathrm{A}=>\mathrm{B})=\frac{26,50}{30,77} \times 100=86,11$

Tabel 5. Rule Asosiasi

\begin{tabular}{|c|l|c|c|c|}
\hline No & \multicolumn{1}{|c|}{$\mathbf{X = >}$} & $\begin{array}{c}\text { Confidence } \\
(\%)\end{array}$ & $\begin{array}{c}\text { Nilai Uji } \\
\text { lift }\end{array}$ & $\begin{array}{c}\text { Korelasi } \\
\text { rule }\end{array}$ \\
\hline 1 & $\begin{array}{l}\text { Metronidazole Inj 5mg/ml - 100ml , } \\
\text { Amoxicilin => Abate }\end{array}$ & 100,00 & 4,68 & $\begin{array}{c}\text { korelasi } \\
\text { positif }\end{array}$ \\
\hline 2 & $\begin{array}{l}\text { Amoxicilin , Abate => Metronidazole } \\
\text { Inj 5mg/ml - 100ml }\end{array}$ & 80,00 & 3,12 & $\begin{array}{c}\text { korelasi } \\
\text { positif }\end{array}$ \\
\hline 3 & $\begin{array}{l}\text { Abate, Metronidazole Inj 5mg/ml - } \\
\text { 100ml => Amoxicilin }\end{array}$ & 100,00 & 4,33 & $\begin{array}{c}\text { korelasi } \\
\text { positif }\end{array}$ \\
\hline 4 & $\begin{array}{l}\text { Metronidazole Inj 5mg/ml - 100ml => } \\
\text { Abate, Amoxicilin }\end{array}$ & 66,67 & 3,12 & $\begin{array}{c}\text { korelasi } \\
\text { positif }\end{array}$ \\
\hline 5 & $\begin{array}{l}\text { Amoxicilin => Metronidazole Inj } \\
\text { 5mg/ml - 100ml, Abate }\end{array}$ & 74,07 & 4,33 & $\begin{array}{c}\text { korelasi } \\
\text { positif }\end{array}$ \\
\hline 6 & $\begin{array}{l}\text { Abate => Amoxicilin , Metronidazole } \\
\text { Inj 5mg/ml - 100ml }\end{array}$ & 80,00 & 4,68 & $\begin{array}{c}\text { korelasi } \\
\text { positif }\end{array}$ \\
\hline
\end{tabular}

Tabel 5 merupakan hasil rule asosiasi setelah melakukan proses dari perhitungan support dan confidence. Akan mendapatkan hasil analisa seperti di bawah ini. 
Tabel 6. Hasil Analisa

\begin{tabular}{|c|l|c|}
\hline No & \multicolumn{1}{|c|}{ Rule } & Confidence (\%) \\
\hline 1 & $\begin{array}{l}\text { Jika konsumen membeli Metronidazole Inj 5mg/ml - 100ml, } \\
\text { Amoxicilin, maka konsumen juga akan membeli Abate }\end{array}$ & 100,00 \\
\hline 2 & $\begin{array}{l}\text { Jika konsumen membeli Amoxicilin, Abate, maka konsumen } \\
\text { juga akan membeli Metronidazole Inj 5mg/ml -100ml }\end{array}$ & 80,00 \\
\hline 3 & $\begin{array}{l}\text { Jika konsumen membeli Abate, Metronidazole Inj 5mg/ml } \\
\text { 100ml, maka konsumen juga akan membeli Amoxicilin }\end{array}$ & 100,00 \\
\hline 4 & $\begin{array}{l}\text { Jika konsumen membeli Metronidazole Inj 5mg/ml - 100ml, } \\
\text { maka konsumen juga akan membeli Abate, Amoxicilin }\end{array}$ & 66,67 \\
\hline 5 & $\begin{array}{l}\text { Jika konsumen membeli Amoxicilin, maka konsumen juga } \\
\text { akan membeli Metronidazole Inj 5mg/ml - 100ml, Abate }\end{array}$ & 74,07 \\
\hline 6 & $\begin{array}{l}\text { Jika konsumen membeli Abate, maka konsumen juga akan } \\
\text { membeli Amoxicilin, Metronidazole Inj 5mg/ml - 100ml }\end{array}$ & 80,00 \\
\hline 7 & $\begin{array}{l}\text { Jika konsumen membeli Ceftriaxone Inj 1.0g, maka } \\
\text { konsumen juga akan membeli Cream Otot Geliga 30gr }\end{array}$ & 86,11 \\
\hline
\end{tabular}

Tabel 6 diatas merupakan tabel hasil analisa dari data mining menggunakan algoritma apriori dengan nilai support $20 \%$ dan nilai confidence $50 \%$.

\section{KESIMPULAN}

Sesuai dengan pembahasan mengenai aplikasi data mining menggunakan metode Apriori, maka kesimpulan yang dapat diambil dari penelitian ini adalah sebagai berikut:

a. Penggunaan data mining menggunakan algoritma apriori dapat diimplementasikan pada sistem pengadaan barang untuk prediksi pola kombinasi itemset dan rule sebagai informasi penjualan.

b. Penerapan algoritma apriori pada penjualan obat untuk melihat pola penjualan konsumen dimana pada saat pengolahan data dapat kita ketahui obat yang sering dibeli.

\section{SARAN}

Saran yang diberikan untuk pengembangan penelitian ini adalah sebagai berikut:

a. Melakukan perbandingan terhadap hasil metode data mining yang satu dengan yang lainnya untuk dapat sehingga mendapatkan perbandingan mana algoritma yang lebih baik untuk diterapkan.

b. Melakukan pengembangan penelitian agar pada penelitian selanjutnya diharapkan sistem melakukan perbandingan terhadap atribut selain jenis data obat yang ada di Apotik.

\section{DAFTAR PUSTAKA}

[1] Han, J., Kamber, M., Pei, J., 2012, Data Mining: Concepts and Techniques, Ed. 3, Morgan Kauffman Publishers, Waltham. 
[2] Yanto, R., Kesuma, H.D., 2017, Pemanfaatan Data Mining untuk Penempatan Buku di Perpustakaan Menggunakan Metode Association Rule, Jurnal Jatisi, Vol. 4, No.1, pp. 110.

[3] Tampubolon, K., Saragih, H., Reza, B., 2013, Implementasi Data Mining Algoritma Apriori pada Sistem Persediaan Alat-alat Kesehatan, Majalah Ilmiah INTI (Informasi dan Teknologi Ilmiah), Vol. 1, No. 1, pp. 93-106.

[4] Gunadi, G., Sensuse, D.I., 2012, Penerapan Metode Data Mining Market Basket Analysis Terhadap Data Penjualan Produk Buku dengan Menggunakan Algoritma Apriori dan Frequent Pattern Growth (FP-Growth): Studi Kasus Percetakan PT. Gramedia, Jurnal Telematika MKOM, Vol. 4, No.1, pp. 118-132.

[5] Nofriansyah, D., Erwansyah, K., Ramadhan, M., 2016, Penerapan Data Mining dengan Algoritma Nä̈ve Bayes Clasifier untuk Mengetahui Minat Beli Pelanggan Terhadap Kartu Internet XL (Studi Kasus di CV. Sumber Utama Telekomunikasi), Jurnal SAINTIKOM, vol.15, No. 2, pp. 81-92.

[6] Nurjoko, Kurniawan, H., 2016, Aplikasi Data Mining untuk Memprediksi Tingkat Kelulusan Mahasiswa Menggunakan Algoritma Apriori di IBI Darmajaya Bandar Lampung, Jurnal TIM Darmajaya, vol. 02, No. 01, pp. 79-93.

[7] Salamah, E.N., Ulinnuha, N., 2017, Analisis Pola Pembelian Obat dan Alat Kesehatan di Klinik Ibu dan Anak Graha Amani dengan Menggunakan Algoritma Apriori, Jurnal INFORM, Vol.2, No.1, pp. 1-6.

[8] Jayadi, Patombongi, A., 2017, Implementasi Aplikasi Data Mining pada Apotek Kimia Farma Bahteramas Menggunakan Algoritma Apriori, Jurnal SIMTEK, Vol. 2, No. 1, pp. 87-95.

[9] Kolkas, M.K., El-Bakry, H.M., Saleh, A.A., 2014, Integrated Data Mining Techniques in Enterprise Resouces Planning (ERP) Systems, International Journal of Information Sciences and Intelligent System, Vol. 3, No. 2, pp. 131-152.

[10] Kusrini, Luthfi, E.T., 2009, “Algoritma Data Mining”, Andi, Yogyakarta.

[11] Sutradana, G.C., Wahyudi, M.D.R., 2017, Penerapan Data Mining untuk Analisis Pengaruh Lama Studi Mahasiswa Teknik Informatika UIN Sunan Kalijaga Yogyakarta Menggunakan Metode Apriori, Jurnal Informatika Sunan Kalijaga JISKA, Vol. 1, No. 3, pp. 153-162.

[12] Ristianingrum, Sulastri., 2017, Implementasi Data Mining Menggunakan Algoritma Apriori, Prosiding SINTAK, Vol. 2, No. 2, pp. 31-39.

Saputra, et., al (Implementasi Data Mining Menggunakan Algoritma Apriori Untuk Meningkatkan Pola Penjualan Obat) 